\title{
STUDY OF MORPHOLOGY AND HORMONE RECEPTOR STATUS OF MALE BREAST LESIONS
}

\author{
Prema N. S1, Jyotsna Nair ${ }^{2}$
}

${ }^{1}$ Additional Professor, Department of Pathology, Government Medical College, Kollam, Kerala.

${ }^{2}$ Assistant Surgeon, Department of Health Services, District Hospital, Aluva, Kerala.

\section{ABSTRACT}

\section{BACKGROUND}

Male breast carcinoma is rare and therefore not detected on time. They also do not receive importance in studies. All male breast carcinomas received during the given period in Pathology Department at Government Medical College, Trivandrum were studied, graded, categorised, interpreted as per relevant standards and sub-typed according to their immunohistochemical profile. Appropriate statistical correlations have been applied. Hormonal study of these lesions helps to decide proper targeted chemotherapy for these cases and help in further treatment. In case of benign lesions like gynaecomastia, it can be useful in treating them with drug therapy so that patients can do away with unwanted surgeries and hassles. In view of the higher fatality rate, male breast cancers merit more serious study and early intervention.

The objectives of this article are to study the clinico-pathological features of Male Breast Lesions and to assess the expression of Oestrogen Receptor and Progesterone Receptor in male breast lesions and also HER-2/neu in male breast carcinomas.

\section{MATERIALS AND METHODS}

The present study was of descriptive design and was conducted in the Department of Pathology, Medical College, Trivandrum. All male breast lesions were received in the Department of Pathology, Medical College, Trivandrum during the period from 2008 to 2013. Clinical details and macroscopic features of all male breast lesions received during the study period were studied as per proforma. Formalin-fixed, paraffin-embedded sections were stained with haematoxylin and eosin. Grading of the malignancy was done as per Nottingham modification of the Scarff-Bloom-Richardson's grading system. Oestrogen Receptor (ER), Progesterone Receptor (PR) and HER-2/neu study was done in all cases of carcinoma breast and Oestrogen Receptor and Progesterone Receptor study was done in representative cases of gynaecomastia. Procedure for Immunohistochemistry is given in Appendix II. ER-PR nuclear stains and HER-2/neu will be categorised as positive or negative. The interpretation for ER-PR will be as per Allred Scoring guidelines and for HER-2/neu. The carcinoma cases were then subtyped according to the immunohistochemical profile. All data is entered in Microsoft Excel and proportions were calculated.

\section{RESULTS}

The present study included 368 male breast lesions received in the Department of Pathology, Medical College, Trivandrum. 354 cases were benign lesions and 14 cases were breast carcinoma. Of the benign lesions the maximum obtained were of Gynaecomastia 348 (98.3\%). Other benign lesions included fat necrosis, acute and chronic inflammation. Histopathology showed majority of the cases (100 cases) to be in the intermediate stage of gynaecomastia. ER-PR study in 20 cases of gynaecomastia showed oestrogen receptor positivity in 14 cases (70\%) with a mean score of 4.75 . Progesterone receptor was positive in 18 cases $(90 \%)$ with a mean score of 5.55. Among the 14 carcinoma patients, the mean age was found to be 65.5 years. In the present study, all cases were of infiltrating ductal carcinoma; 4 had positive margin status, the nipple and areola were involved in 5 cases and no vascular invasion was noted. Majority of the cases, 12 cases (85.71\%) belonged to Grade II (Modified Bloom Richardson grading). In the 4 modified radical mastectomy specimens, the lymph node showed metastases in 2 cases $(4 / 7$ showed metastases and $1 / 10$ showed metastases); 13 cases (92.8\%) were found to be Oestrogen Receptor (ER) and Progesterone Receptor (PR) positive and all cases were HER-2/neu negative. By this panel of immunohistochemical markers, 13 cases (92.8\%) were categorised as Luminal A (ER+, PR+, HER-2/neu-) and 1 case was ER, PR and HER-2/neu negative.

\section{CONCLUSION}

This study proposes to evaluate the clinico-morphological details of these rare lesions and correlate them with the histology, grade and hormone receptor status. Hormonal study of these lesions will help in advocating the proper targeted chemotherapy for these cases and help in adjunct treatment. The expression of hormonal status in benign lesions like gynaecomastia can be useful in treating these lesions with drug therapy, so patients can do away with unwanted surgeries and hassles. Also in view of the higher fatality rate, male breast cancers merit more serious study and early intervention.

\section{KEYWORDS}

Gynaecomastia, Male Breast Cancer, Male Breast Neoplasms.

HOW TO CITE THIS ARTICLE: Prema NS, Nair J. Study of morphology and hormone receptor status of male breast lesions. J. Evolution Med. Dent. Sci. 2017;6(57):4249-4256, DOI: 10.14260/Jemds/2017/921

Financial or Other, Competing Interest: None.

Submission 15-03-2017, Peer Review 04-07-2017,

Acceptance 12-07-2017, Published 17-07-2017.

Corresponding Author:

Dr. Jyotsna Nair,

'Dwaraka' 4/209, Mana Lane,

Convent Road 2,

Thotakatukara, Aluva, Cochin-683108.

E-mail: jnair6@gmail.com

DOI: $10.14260 /$ jemds $/ 2017 / 921$

\section{BACKGROUND}

Male breast lesions have proven to be challenging to treat for clinicians and to diagnose for radiologists and pathologists primarily due to their rarity.

Male breast lesions can be either benign or malignant. The majority of lesions include gynaecomastia and cancers. The benign cases such as those in infancy or puberty and even in old age do not merit serious consideration or even intervention. ${ }^{1}$ The benign breast lesions in males chiefly constitute gynaecomastia, ${ }^{2}$ which accounts for about $15 \%$ 
cases worldwide. It is found to involve left side more in unilateral cases. $^{3}$ As male breast cancer is uncommon, accounting for not more than $1 \%$ of all breast carcinomas, $4,5,6$ it is seldom suspected by the patient or by his doctor and as a result the disease often progresses to an advanced stage when it is diagnosed. In Regional Cancer Centre, Thiruvananthapuram, there were $15(0.85 \%)$ cases in 2011 and $23(1.2 \%)$ cases of male breast cancers in 2012. Due to its rarity, male breast cancers do not receive adequate attention in studies when compared to similar lesions in women. This study proposes to evaluate the clinico-morphological features of male breast carcinomas and correlate them with the histology, grade and hormone receptor status. Hormonal study of these lesions will help in advocating the proper targeted chemotherapy for these cases and help in adjunct treatment. ${ }^{7}$ This study also shows that the expression of hormonal status in benign lesions like gynaecomastia can be useful in treating these lesions with drug therapy, so patients can do away with unwanted surgeries and hassles. The objectives of this article are to study the clinico-pathological features of Male Breast Lesions and to assess the expression of Oestrogen Receptor and Progesterone Receptor in male breast lesions and also HER-2/neu in male breast carcinomas.

\section{MATERIALS AND METHODS}

The present study was conducted in the Department of Pathology, Government Medical College, Trivandrum. The study design was descriptive type. Clinical details and macroscopic features of all male breast lesions received during the study period were studied. Formalin fixed, paraffin embedded sections were stained with haematoxylin and eosin. Microscopic features were studied and grading of the malignancy cases was done as per Nottingham modification of the Scarff-Bloom-Richardson's Grading system. Immunohistochemical (IHC) study with Oestrogen Receptor (ER), Progesterone Receptor (PR) and HER-2/neu study were done in all cases. The interpretation for ER-PR was done as per Allred Scoring guidelines. The cases were then subtyped according to their immunohistochemical profile. Oestrogen Receptor and Progesterone Receptor study were done in representative cases of gynaecomastia. All data were entered in Microsoft Excel and proportions were calculated.

\section{RESULTS}

Of the total 368 cases in 5 years, the majority of cases were benign (96\%) and only $4 \%$ of the cases were malignant.

\section{Benign Lesions}

A total of 348 benign lesions were studied, of which the vast majority consisted of Gynaecomastia (98.3\%). There were 3 cases of fat necrosis, 1 case of acute inflammation and 2 cases of chronic inflammation (Refer Table 1).

\begin{tabular}{|c|c|c|}
\hline Lesion & Number & Percentage \\
\hline Gynaecomastia & 348 & 98.3 \\
\hline Fat necrosis & 3 & 0.84 \\
\hline Abscess & 1 & 0.28 \\
\hline Chronic Inflammation & 2 & 0.56 \\
\hline Total & $\mathbf{3 5 4}$ & $\mathbf{1 0 0}$ \\
\hline \multicolumn{2}{|c|}{ Table 1. Types of Benign Lesions } \\
\hline
\end{tabular}

\section{Gynaecomastia}

Age

Of the 348 gynaecomastia cases, the majority of cases were in the age group of 20 to 29 years (38.2\%). The youngest was 10 years old and the oldest case was 79 years old. Mean age was calculated to be 65.5 years.

\section{Clinical Features}

176 cases of gynaecomastia were contacted and their clinical features were enquired; 20 cases were smokers and drug intake of Finasteride was noted in only 1 case. All followed up cases had no other obvious comorbidities (diseases of liver, kidney or prostate).

\section{Duration of Symptoms}

Of all the 348 cases of gynaecomastia, the maximum number of patients were in the group of $\leq 6$ months' duration.

\section{Site}

Of the total cases of gynaecomastia in this study, left breast alone was affected in $39.6 \%$ cases.

\section{Gross Specimens}

The excision biopsy specimens received in our department showed yellowish lobulated appearance with areas of fibrosis.

\section{Histopathology of Gynaecomastia}

The cases were histopathologically reported as gynaecomastia, of which 197 were studied in detail. All the three variants were seen namely- Florid, Intermediate and Fibrous gynaecomastia. In our study, the majority of cases were Intermediate type $(50.76 \%)$ followed by Florid Gynaecomastia (25.38\%) (Refer Table 2).

\begin{tabular}{|c|c|c|}
\hline Cases & Number & Percentage \\
\hline Florid & 50 & 25.38 \\
\hline Intermediate & 100 & 50.76 \\
\hline Fibrous & 47 & 23.85 \\
\hline Total & $\mathbf{1 9 7}$ & $\mathbf{1 0 0}$ \\
\hline Table 2. Histopathology Types of Gynaecomastia \\
\hline
\end{tabular}

\section{Other Benign Lesions}

The other benign lesions included fat necrosis, acute and chronic inflammation.

\section{Immunohistochemistry}

The Oestrogen receptor and Progesterone receptor status of 20 cases were done as per the protocol. Of the 20 cases, 14 cases $(70 \%)$ were Oestrogen receptor positive. The maximum score obtained was 8 and minimum was 0 . The average score was 4.75 .

Progesterone receptor was positive in 18 cases (90\%) with a score ranging from 0 to 8 . The average score was calculated to be 5.55 .

\section{Malignant Lesions Clinical Features}

- 14 cases of male breast carcinoma were received in the study period from January 2008 to June 2013.

- $\quad$ The age group of patients in our study ranged from 37 to 85 years. The mean age was found to be 65.5 years. 
- $\quad$ All of them presented with breast lump, of which 4 cases had fungating mass at presentation; 7 cases had pain.

- None had any complaints of nipple discharge. None of the cases had a positive family history of breast cancer. None of the cases had a history of recurrence.

- Maximum number of cases had complaints of breast lump for a year (78.57\%); 3 cases suffered from disease for more than 1 year.

- $\quad$ Of the 14 cases, 9 cases involved the right breast and 5 cases involved the left side.

- Out of 14 cases, modified radical mastectomy was done in 4 cases (Refer Table 3).

\section{Types of Surgery}

\begin{tabular}{|c|c|c|}
\hline Type of Surgery & Number & Percentage \\
\hline Simple mastectomy & 2 & 14.28 \\
\hline $\begin{array}{l}\text { Modified radical } \\
\text { mastectomy }\end{array}$ & 4 & 28.57 \\
\hline Lumpectomy & 3 & 21.4 \\
\hline Toilet mastectomy & 2 & 14.28 \\
\hline Trucut biopsy & 3 & 21.4 \\
\hline Total & 14 & 100 \\
\hline \multicolumn{3}{|c|}{$\begin{array}{c}\text { Table 3. Types of Surgery done in Male Breast Carcinome } \\
\text { Patients }\end{array}$} \\
\hline
\end{tabular}

\section{Macroscopic Features}

Of the 11 cases of breast carcinomas in which mastectomy/lumpectomy was done, the tumour size, margins of excision, base of excision, other features like necrosis and haemorrhage were assessed and lymph node sampling was done. The cut surface of tumours was ill circumscribed, greywhite in colour and firm in consistency. Tumour size ranged from $0.5 \mathrm{cms}$ to $8 \mathrm{cms}$; 4 of the cases showed haemorrhage and 2 of them had necrosis.

\section{Microscopic Features}

All cases were of infiltrating ductal carcinomas. No special type (IDC-NST). The neoplastic cells were arranged in glandular pattern, nests, sheets and papillary patterns. Individual cells were mostly moderately pleomorphic with increased nuclear cytoplasmic ratios, moderate eosinophilic cytoplasm and round-to-oval hyperchromatic nuclei with irregularly clumped chromatin. Mitotic figures ranged from 8-15/10 HPF (High Power Fields). Foci of calcification were seen.

\section{Grade}

All the tumours were graded as per Modified BloomRichardson grading.8,9,10 Majority of the cases belonged to Grade II (85.71\%). Grade I cases were 14.29\%.

\section{Margins}

In the present study, out of 11 cases 4 had positive margin status, 3 cases were exempted as they were trucut biopsies.

\section{Lymph Node Status}

Lymph node sampling was done in all mastectomy specimens. The lymph nodes showed metastases in 2 cases- 4 out of 7 nodes in one and 1 out of 10 nodes in others were positive for metastases.

\section{Vascular Invasion}

Vascular invasion was assessed in 11 out of 14 cases excluding trucut biopsies. None of the cases showed vascular invasion.

\section{Adjacent Breast Changes}

Of all the cases of breast carcinoma studied, 5 specimens showed fibrosis in adjacent breast.

\section{Immunohistochemistry}

All 14 cases were scored and immunohistochemistry was done on the paraffin-embedded blocks as per standard IHC protocol.

\section{ER PR Status}

13 cases $(92.8 \%)$ were found to be both Oestrogen Receptor (ER) and Progesterone Receptor (PR) positive. One case in both ER and PR were negative.

\section{Scoring}

The ER and PR were scored according to the Allred scoring system. The score for ER ranged from 0 to 8 and the average score was found to be 5.72 . The score for PR ranged from 0 to 8 and the average score was calculated to be 6 (Refer Table 4 and 5).

\begin{tabular}{|c|c|c|}
\hline Immunohistochemistry & Number & Percentage \\
\hline ER Positive & 13 & 92.8 \\
\hline ER Negative & 1 & 7.2 \\
\hline Total & 14 & 100 \\
\hline \multicolumn{3}{|c|}{$\begin{array}{l}\text { Table 4. Male Breast Carcinoma Cases with IHC-ER } \\
\text { (Oestrogen Receptor) Status }\end{array}$} \\
\hline
\end{tabular}

\begin{tabular}{|c|c|c|}
\hline Immunohistochemistry & Number & Percentage \\
\hline PR Positive & 13 & 92.8 \\
\hline PR Negative & 1 & 7.2 \\
\hline Total & 14 & 100 \\
\hline \multicolumn{3}{|c|}{$\begin{array}{l}\text { Table 5. Male Breast Carcinoma Cases with IHC-PR } \\
\text { (Progesterone Receptor) Status }\end{array}$} \\
\hline
\end{tabular}

\section{HER-2/Neu Expression}

All were found to be HER-2/neu negative.

\section{Typing}

By this panel of immunohistochemical markers, 13 cases (92.8\%) were categorised as Luminal A (ER+, PR+, HER2/neu-) according to Kornegoor $\mathrm{R}$ et al. ${ }^{11}$ The remaining 1 case was ER, PR and HER-2/neu negative. 


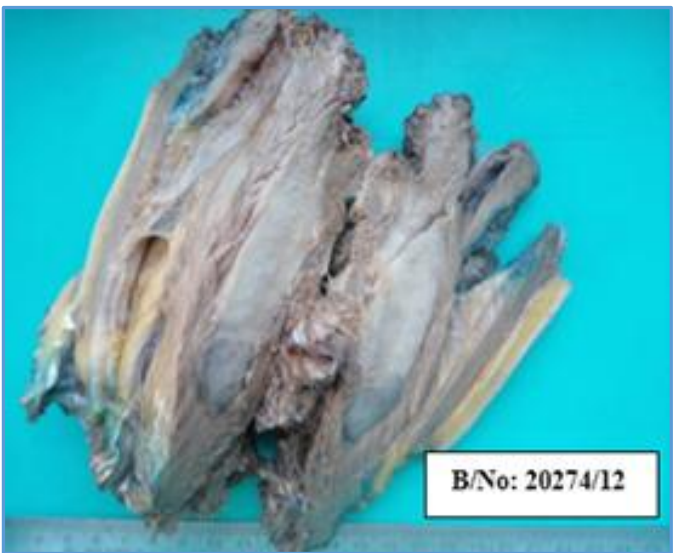

Figure 1. Cut Section of Male Breast Specimen showing Tumour Breast

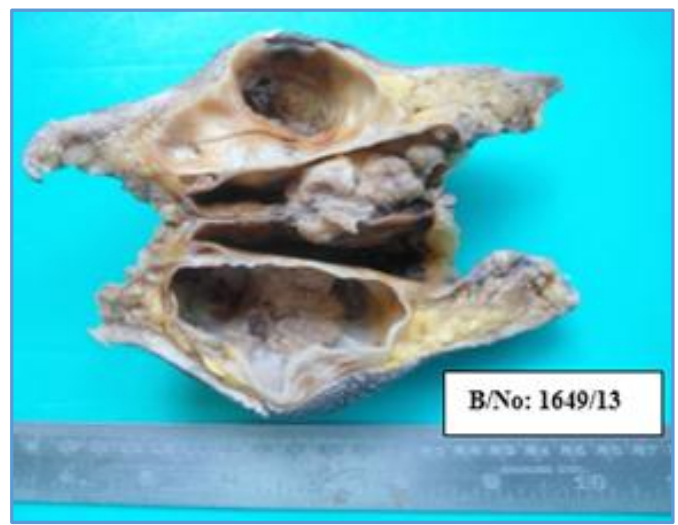

Figure 2. Cut Section of Male Specimen showing Cystic Areas

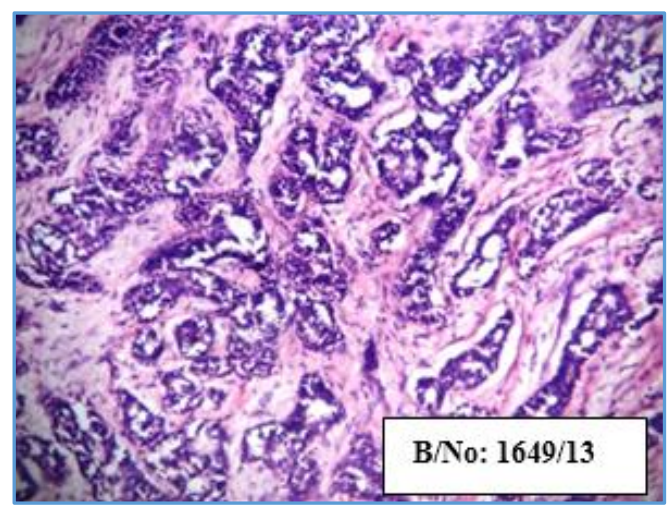

Figure 3. Tumour Cells in Glandular Pattern (100X)

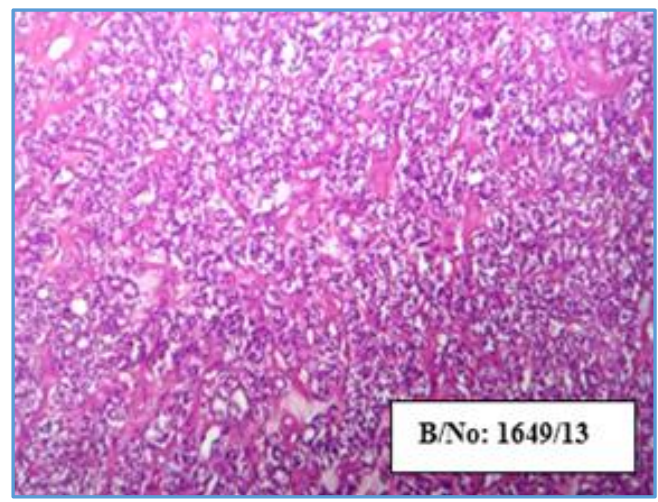

Figure 4. Tumour Cells in Acinar Pattern (100X)

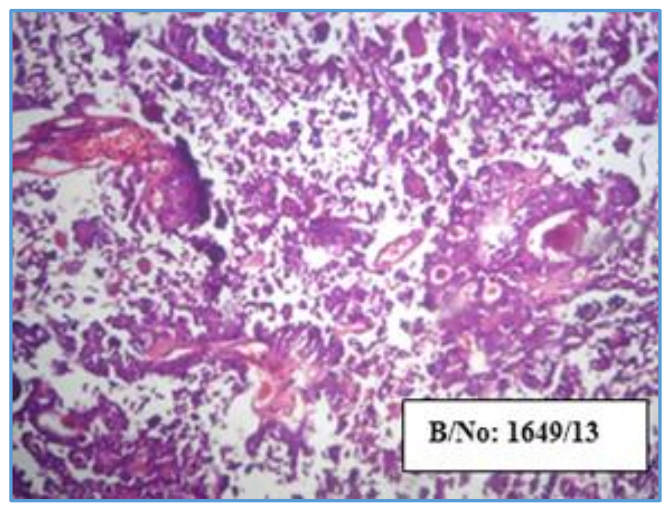

Figure 5. Tumour Cells in Papillary Pattern with Foci of Calcification (100X)

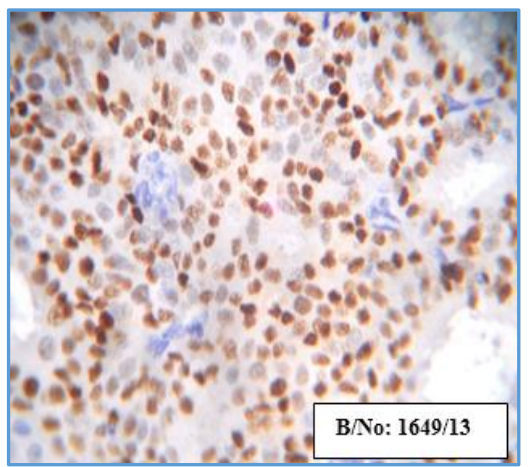

Figure 6. Tumour Cells showing ER Strong Positivity (Carcinoma Breast) (400X)

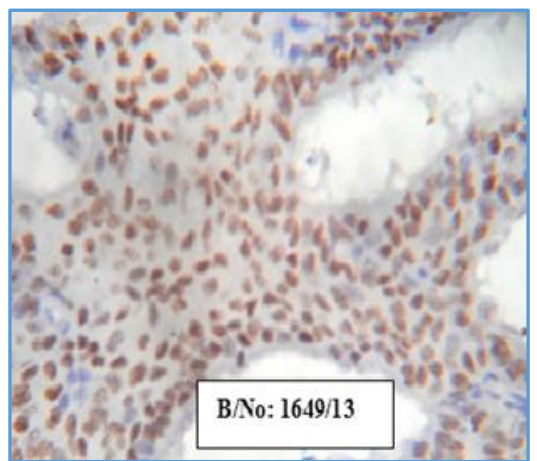

Figure 7. Tumour Cells showing PR Strong Positivity (Carcinoma Breast) (400X)

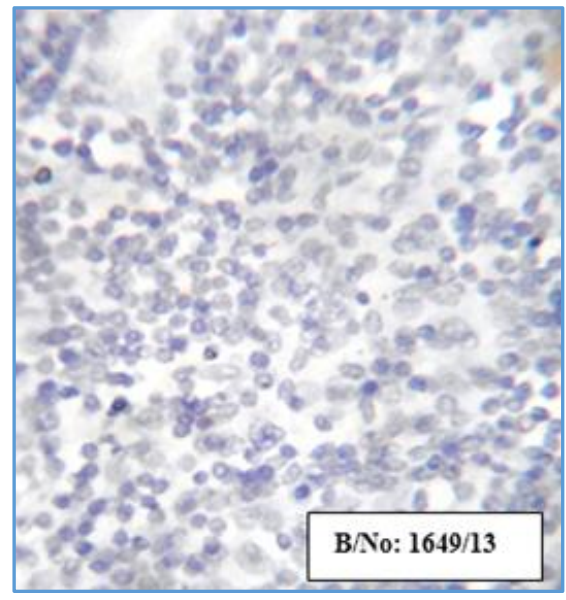

Figure 8. Tumour Cells showing HER-2/Neu Negativity (Carcinoma Breast) (400X) 


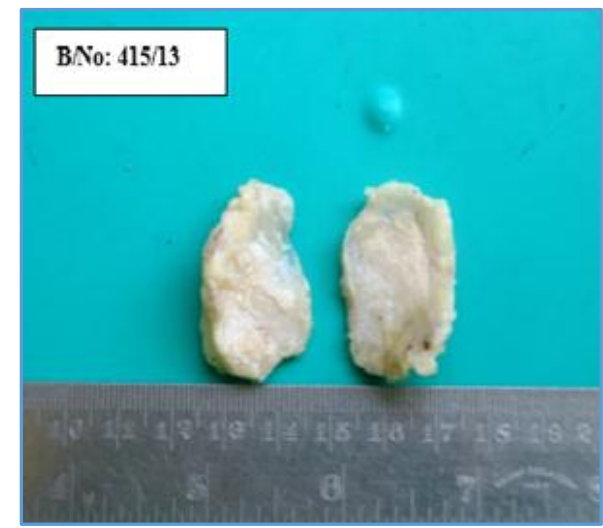

Figure 9. Cut Section of Gynaecomastia SpecimenYellowish Lobulated with Whitish Areas

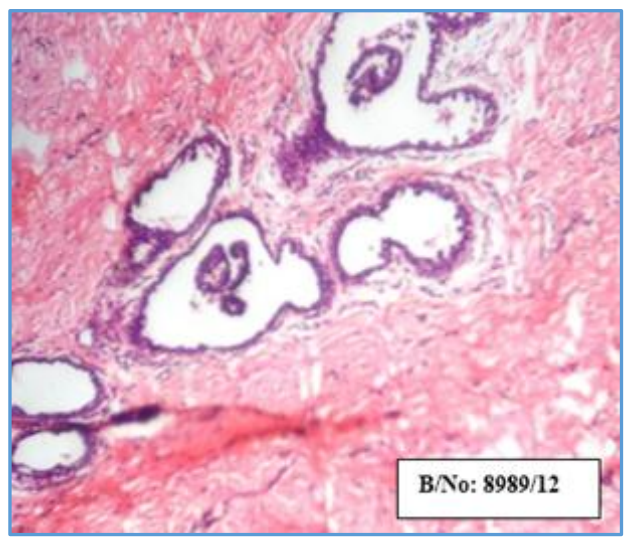

Figure 10. Gynaecomastia Florid Type (100X)

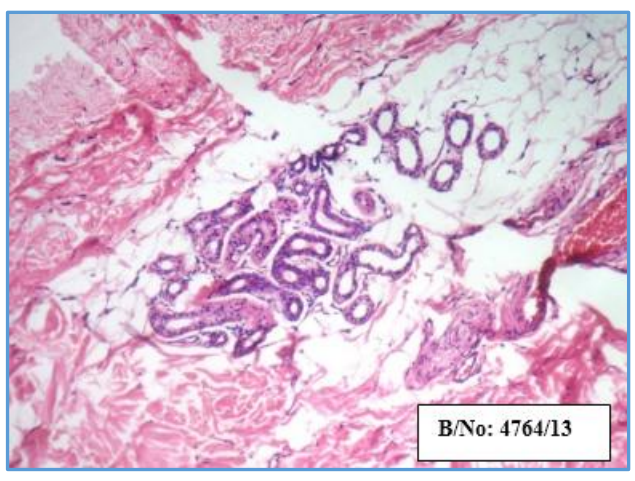

Figure 11. Gynaecomastia Intermediate Type (100X)

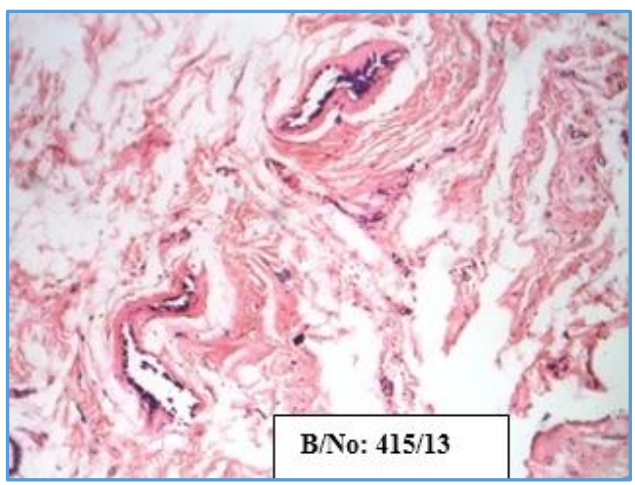

Figure 12. Gynaecomastia

Fibrous Type (100X)

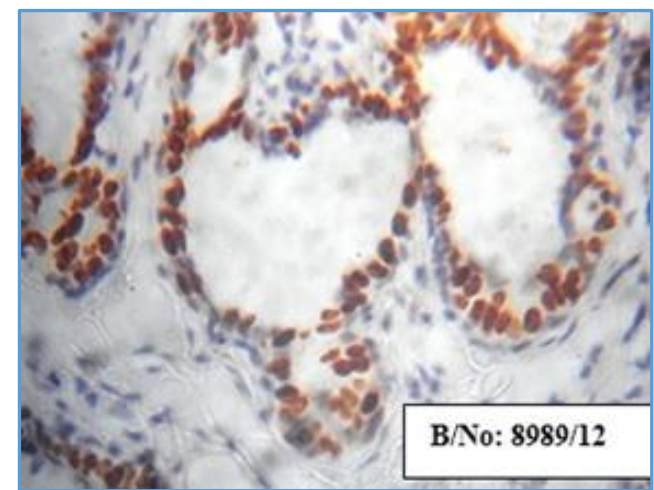

Figure 13. Ductal Epithelial Cells showing ER Strong Positivity (Gynaecomastia) (400X)

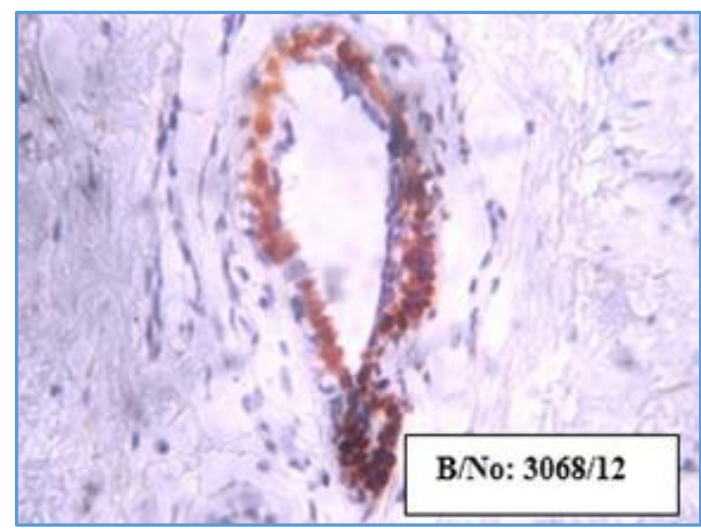

Figure 14. Ductal Epithelial Cells showing PR Intermediate Positivity (Gynaecomastia) (400X)

\section{DISCUSSION}

The aim of this study is to evaluate the clinico-morphological details of male breast lesions. Hormonal study of these lesions will help in advocating the proper targeted chemotherapy for these cases and help in adjunct treatment. The study of expression of hormonal status in benign lesions like gynaecomastia will help in planning drug therapy and patients can do away with unwanted surgeries.

The present study included all male breast lesions received in the Department of Pathology, Medical College, Trivandrum during the period from 2008 to 2013. A total of 368 cases of male breast lesions were studied.

The majority of lesions obtained were benign and breast cancer formed only $4 \%$ of the total number of cases.

of the benign lesions, the majority were gynaecomastia (98.3\%). Others included fat necrosis, chronic inflammation and abscess. Similar findings were noted in our reference studies, i.e. Martin Nydick et $\mathrm{al}^{1}$ (1961) and Biro FM et $\mathrm{al}^{3}$ (1990).

Of the 348 gynaecomastia cases, the maximum age group affected in this study was between the ages of 20 and 29 years, i.e. 133 cases (38.2\%). This was in contrast to other studies, which showed a more pubertal preponderance.

The majority of patients were cases of unilateral gynaecomastia in contrast to previous study by Biro et al. ${ }^{3}$ However, in unilateral cases the left breast was affected more as in the study conducted by Bannayan GA and Hajdu SI. ${ }^{12}$ 
However, in the study by Biro et $\mathrm{al}^{3}$ right breast was more affected.

\section{Histopathology}

All the three types of gynaecomastia have been obtained namely- florid, fibrous and intermediate. The florid type has increased ductular tissue and vascularity. The fibrous type has more stromal fibrosis and few ducts. The intermediate type is a mixture of the two. The majority of cases were of Intermediate type- 100 cases $(50.76 \%)$.

\section{Other Benign Lesions}

The other lesions in our study included fat necrosis, acute and chronic inflammation only.

\section{Immunohistochemistry}

Of the 20 cases of gynaecomastia, 14 cases $(70 \%)$ were found to be Oestrogen receptor positive. The maximum score obtained was 8 and minimum was 0 . The average score was 4.75 .

Progesterone receptor was positive in 18 cases (90\%) with a score ranging from 0 to 8 . The average score was calculated to be 5.55 .

In a study by Sasano $\mathrm{H}$ et al,13 hormone receptor study of gynaecomastia cases was performed. Oestrogen Receptor (ER) and Progesterone Receptor (PR) expression was noted in all the ductal epithelial cells in gynaecomastia. However, Kornegoor $\mathrm{R}$ et $\mathrm{al}^{11}$ studied 46 cases of gynaecomastia immuno-histochemically and found the normal ductal male breast epithelial cells to be Oestrogen Receptor positive in $69 \%$ cases and progesterone receptor positive in $39 \%$ cases of Gynaecomastia.

\section{Malignant Lesions of Male Breast \\ Breast Carcinoma}

In the present study done in the Department of Pathology Government Medical College, Thiruvananthapuram, we received 14 cases of male breast carcinoma in the specified time period.

\section{Clinical Features}

All of the 14 cases presented with lump breast and this was similar to the finding mentioned by Shawky et al ${ }^{14}$ and Rosen. However, in the study by Scheike $0^{15}$ only $13 \%$ cases had a palpable lump. According to Sharon H Giordano ${ }^{16}$ most of the patients presented with painless lump, ulceration and nipple discharge. In our study, 4 patients had only fungation and none had any discharge per nipple; $50 \%$ of the patients however complained of pain. Symptoms progress rapidly between 6 months ${ }^{17}$ and 1 year. ${ }^{18}$ None of the patients had any family history of breast cancer. Positive family history of breast carcinomas associated with $27 \%$ of male breast carcinomas treated at the Mayo Clinic was found by Gough et $\mathrm{al}^{19,20,21,22}$ and Shawky et $\mathrm{al}^{14}$ found a single case with a positive family history. Other risk factors include alcohol, obesity, liver diseases and tuberculosis. ${ }^{23,19,24}$

The age group of patients in our study ranged from 37 to 85 years. The mean age of the 14 cases was found to be 65.5 years and this was similar to other studies, i.e. Rosen Paul Peter and Shawky et al (2013).
In our study, the majority of cases had right breast cancer (64.28\%). This was in contrast to the study by Sharon $\mathrm{H}$ Giordano et al ${ }^{16}$ and Shawky et al, ${ }^{14}$ who observed a left-sided preponderance in male breast carcinomas.

The surgeries done are usually Mastectomy,25,26,27 as in our hospital.

\section{Macroscopic Features}

\section{Changes in Tumour}

Of the 11 gross specimens of male breast carcinomas, the cut surfaces of tumours were ill-circumscribed, grey-white in colour, firm in consistency as described in Rosen. ${ }^{28}$ Tumour size ranged from $0.5 \mathrm{cms}$ to $8 \mathrm{cms}$. In a study by Shawky et al, ${ }^{14}$ the tumour size ranged from $1.5 \mathrm{cms}$ to $8 \mathrm{cms} ; 4$ of the gross specimens had haemorrhage and 2 of them had necrosis. Rosen also describes similar findings. Papillary carcinomas may have solid and cystic components with areas of haemorrhage, ${ }^{29,14}$ which was not seen in our study.

\section{Histopathology}

All cases were infiltrating ductal carcinomas. The neoplastic cells were arranged in glandular pattern, nests, sheets and papillary patterns. Individual cells were mostly moderately pleomorphic with increased nuclear cytoplasmic ratios, moderate eosinophilic cytoplasm and round-to-oval hyperchromatic nuclei with irregularly clumped chromatin. Mitotic figures ranged from 8-15/10 HPF (High Power Fields). Foci of calcification were noted.

Other uncommon types of invasive carcinoma in the male breast include medullary,30 mucinous,30,31 adenoid cystic ${ }^{32}$ tumours and carcinoma with osteoclast-like giant cells. ${ }^{32}$

Papillary carcinomas are mostly intracystic and noninvasive. ${ }^{33}$ These were, however, not seen in our study.

\section{Grade}

Majority of the cases belonged to Grade II, i.e. 12 cases (85.71\%). This was in accordance with study by Shawky et $\mathrm{al}^{14}(62.1 \%)$.

\section{Margins and Nipple Areola Involvement}

In the present study, out of 11 cases, 4 had positive margin status and involvement of nipple and areola was seen in 5 cases $(35.71 \%)$. Shawky et $a^{14}$ noted a cutaneous invasion of $10.3 \%$.

\section{Lymph Node Status}

In the 4 modified radical mastectomy specimens, the lymph node sampling was done which showed metastases in 2 cases (4/7 showed metastases and 1/10 showed metastases). This was similar to the study by Shawky et al. ${ }^{14}$

\section{Vascular Invasion}

None of the cases showed vascular invasion.

\section{Immunohistochemistry}

13 cases $(92.8 \%)$ were found to be both Oestrogen Receptor (ER) and Progesterone Receptor (PR) positive $\mathrm{e}^{34,35}$ and all cases were HER-2/neu negative. ${ }^{36,37,38}$

The score for ER ranged from 0 to 8 and the average score was found to be 5.72. The score for PR ranged from 0 to 8 and the average score was calculated to be 6 . 
Both were in contrast to the findings by Sasano et $\mathrm{al}^{13}$ and Shawky et al. ${ }^{14}$

In a study by Rudlowski et al ${ }^{37}$ the HER-2/neu positivity was $15.1 \%$, whereas in our study all cases were HER-2/neu negative. Shawky et $\mathrm{al}^{14}$ also found majority of cases to be HER-2/neu negative (79.3\%).

\section{Typing}

By this panel of immunohistochemical markers, 13 cases were categorised as Luminal A (ER+, PR+, HER-2/neu-) and 1 case showed ER-PR and HER-2/neu negativity. Kornegoor R et $\mathrm{al}^{11}$ and Yimin Ge et $\mathrm{al}^{39}$ also had similar findings where the majority of the cases were Luminal A type, i.e. $75 \%$ and $83 \%$ respectively.

\section{CONCLUSION}

- $\quad$ The present study included 368 male breast lesions received in the Department of Pathology, Medical College, Trivandrum.

- 354 cases were benign lesions and 14 cases were of breast carcinoma.

- Of the benign lesions, the maximum obtained were of Gynaecomastia 348 (98.3\%). Other benign lesions included fat necrosis, acute and chronic inflammation.

- Only 20 cases were smokers, drug intake of Finasteride was noted in one case and none of them had obvious comorbidities (liver, kidney or prostate diseases).

- The majority of gynaecomastia cases were in the age group of 20 - 29 years, i.e. 133 cases (38.2\%).

- Histopathology showed majority of the cases (100 cases) to be in the Intermediate stage of gynaecomastia.

- ER-PR study in 20 cases of gynaecomastia showed oestrogen receptor positivity in 14 cases $(70 \%)$ with a mean score of 4.75. Progesterone receptor was positive in 18 cases (90\%) with a mean score of 5.55 .

- Among all the carcinoma cases, the mean age was found to be 65.5 years.

- All patients presented with a lump breast, 4 cases had fungating masses. No one had complaints of nipple discharge.

- In the 14 cases maximum samples obtained were of modified radical mastectomy, i.e. 4 cases $(28.57 \%)$.

- In the present study, all cases were of infiltrating ductal carcinoma. No special type (IDC NST).

- 4 had positive margin status, the nipple and areola were involved in 5 cases and no vascular invasion was noted.

- Majority of the cases, 12 cases (85.71\%) belonged to Grade II (Modified Bloom-Richardson grading).

- In the 4 modified radical mastectomy specimens, the lymph node showed metastases in 2 cases ( $4 / 7$ showed metastases and $1 / 10$ showed metastases).

- 13 cases (92.8\%) were found to be Oestrogen Receptor (ER) and Progesterone Receptor (PR) positive and all cases were HER-2/neu negative. The mean score for ER was found to be 5.72 and for PR was 6 .

- $\quad$ By this panel of immunohistochemical markers, 13 cases (92.8\%) were categorised as Luminal A (ER+, PR+, HER2/neu-) and 1 case was ER-PR and HER-2/neu negative.

\section{ACKNOWLEDGEMENT}

All the respected staffs in the Department of Pathology, Government Medical College, Trivandrum.

\section{REFERENCES}

[1] Nydick M, Bustos J, Dale JH, et al. Gynecomastia in adolescent boys. JAMA 1961;178(5):449-54.

[2] Biro FM, Lucky AW, Huster GA, et al. Hormonal studies and physical maturation in adolescent gynecomastia. The Journal of Paediatrics 1990;116(3):450-5.

[3] Carlson HE. Gynecomastia. N Engl J Med 1980;303(14):795-9.

[4] Mabuchi K, Bross DS, Kessler LL. Risk factors for male breast cancer. J Natl Cancer Inst 1985;74(2):371-5.

[5] Ouriel K, Lotze MT, Hinshaw JR. Prognostic factors of carcinoma of the male breast. Surg Gynecol Obstet 1984;159(4):373-6.

[6] Schottenfeld D, Lilienfeld AM, Diamond H. Some observations on the epidemiology of breast cancer among males. Am J Public Health Nations Health 1963;53(6):890-7.

[7] Romond EH, Perez EA, Bryant J, et al. Trastuzumab plus adjuvant chemotherapy for operable HER2Positive breast cancer. N Engl J Med 2005;353(16): 1673-84.

[8] Norris HJ, Taylor HB. Carcinoma of the male breast. Cancer 1969;23(6):1428-35.

[9] Elston CW, Ellis IO. Pathologic prognostic factors in breast cancer. I. The value of histological grades in breast cancer: experience from a large study with long-term follow-up. Histopathology 1991;19(5):40310.

[10] Bloom HJG, Richardson WW. Histological grading and prognosis in breast cancer: a study of 1409 cases of which 359 have been followed for 15 years. British Journal of Cancer 1957;11(3):359-77.

[11] Kornegoor R, Verschuur-Maes AH, Buerger H, et al. Molecular subtyping of male breast cancer by immunohistochemistry. Mod Pathol 2012;25(3):398404.

[12] Bannayan GA, Hajdu SI. Gynecomastia: clinicopathologic study of 351 cases. Am J Clin Pathol 1972;57(4):431-7.

[13] Sasano H, Kimura M, Shizawa S, et al. Aromatase and steroid receptors in gynecomastia and male breast carcinoma: an immunohistochemical study. Journal of Clinical Endocrinology Metabolism 1996;81(8):30637.

[14] Shawky H, Younes SG, Sadaka E, et al. Male breast cancer: a 10-year review of 29 cases at Tanta University Hospital. Life Science Journal 2013;10(1): 1096-1102.

[15] Scheike 0. Male breast cancer. 5. Clinical manifestations in 257 cases in Denmark. Br J Cancer 1973;28(6):552-61.

[16] Giordano SH. A review of the diagnosis and management of male breast cancer. The Oncologist 2005;10(7):471-9.

[17] Ribeiro G. Male breast carcinoma- a review of 301 cases from the Christie Hospital \& Holt Radium Institute, Manchester. Br J Cancer 1985;51(1):115-9. 
[18] Wolff M, Reinis MS. Breast cancer in the male: Clinicopathologic study of 40 patients and review of the literature. In: Fenoglio M, Wolff M. eds. Progress in surgical pathology. Vol 3. New York, USA: Masson Publishers 1981:77-109.

[19] Casagrande JT, Hanisch R, Pike MC, et al. A casecontrol study of male breast cancer. Cancer Res 1988;48(5):1326-30.

[20] Gough DB, Donohue JH, Evans MM, et al. A 50-year experience of male breast cancer: is outcome changing? Surg Oncol 1993;2(6):325-33.

[21] Easton DF, Steele L, Fields P, et al. Cancer risks in two large breast cancer families linked to BRCA2 on chromosome 13q-12-13. Am J Hum Genet 1987;61: 120-8.

[22] Thorlacius S, Tryggvadottir L, Oladsdottir GH, et al. Linkage to BRCA2 region in hereditary male breast cancer. Lancet 1995;346(8974):544-5.

[23] Lenfant-Pejovic MH, Mlika-Cabanne N, Bouchardy C, et al. Risk factors for male breast cancer: a Franco-Swiss case-control study. Int J Cancer 1990;45(4):661-5.

[24] Rosenblaum PF, Vena JE, Zielezny MA, et al. Occupational exposures associated with male breast cancer. Am J Epidemiol 1994;139(1):30-6.

[25] Ge Y, Sneige N, Eltorky MA, et al. Immunohistochemical characterization of subtypes of male breast carcinoma. Breast cancer Research 2009;11(3):R28.

[26] Gomez-Raposo C, Tévar ZF, Moyano SM, et al. Male breast cancer. Cancer Treatment Reviews 2010;36(6):451-7.

[27] Taber JKA, Morisy LR, Osbahr AJ, et al. Male breast cancer: risk factors, diagnosis and management (Review). Oncology Reports 2010;24(5):1115-20.

[28] Tavassoli. WHO classification of tumours of breast and female genital tract. Lyon: IARC Press 2003:11.

[29] Sonksen CJ, Michell M, Sundaresan M. Case report: intracystic papillary carcinoma of the breast in a male patient. Clin Radiol 1996;51(6):438-9.

[30] Peter RP. Rosen's breast pathology. $3^{\text {rd }}$ edn. Philadelphia: Lippincott Williams \& Wilkins 2009: 17-8.
[31] Burga AM, Fadare O, Lininger RA, et al. Invasive carcinomas of the male breast: a morphologic study of the distribution of histologic subtypes and metastatic patterns in 778 cases. Virchows Arch 2006;449(5): 507-12.

[32] Hittmair AP, Lininger RA, Tavassoli FA. Ductal carcinoma in situ (DCIS) in the male breast: a morphologic study of 84 cases of pure DCIS and 30 cases of DCIS associated with invasive carcinoma--a preliminary report. Cancer 1998;83(10):2139-49.

[33] Genestie C, Zafrani B, Asselain B, et al. Comparison of the prognostic value of Scarff-Bloom-Richardson and Nottingham histological grades in a series of 825 cases of breast cancer: major importance of the mitotic count as a component of both grading systems. Anticancer Research 1998;18(1B):571-6.

[34] Buchholz TA, Katz A, Strom EA, et al. Pathologic tumour size and lymph node status predict for different rates of locoregional recurrence after mastectomy for breast carcinoma patients treated with neoadjuvant versus adjuvant chemotherapy. Int J Radiat Oncol Biol Phys 2002;53(4):880-8.

[35] Wang-Rodriguez J, Cross K, Gallagher S, et al. Male breast carcinoma: correlation of ER, PR, Ki-67, Her2Neu and p53 with treatment and survival, a study of 65 cases. Mod Pathol 2002;15(8):853-61.

[36] Geyer FC, Marchiò C, Reis-Filho JS. The role of molecular analysis in breast cancer. Pathology 2009:41(1):77-88.

[37] Rudlowski C, Friedrichs N, Faridi A, et al. Her-2/neu gene amplification and protein expression in primary male breast cancer. Breast Cancer Res Treat 2004;84(3):215-23.

[38] Fox SB, Rogers S, Day CA, et al. Estrogen receptor and epidermal growth factor receptor expression in male breast carcinoma. J Pathol 1992;166(1):13-8.

[39] Joshi MG, Lee AKC, Loda M, et al. Male breast carcinoma. an evaluation of prognostic factors contributing to a poorer outcome. Cancer 1996;77(3): 490-8. 